\title{
IMPLIKASI ALIRAN FILSAFAT PENDIDIKAN ISLAM PADA MANAJEMEN PENDIDIKAN
}

\author{
Ahmad Salim \\ (Dosen PAI STIA Alma Ata Yogyakarta)
}

\begin{abstract}
The philosophy of Islamic education has less effect on the development of Islamic education journey. The concept of thinking of educational course not only from logical thinking but also from the revelation. It be the pattern of the development process as a key of instruction. There are many Islamic educational philosophy course but writer only discuss the conservative, religious-instrumental rational and pragmatic philosophy in this paper. While the figures to be discussed is Al-Ghazali represents the first course, the Ikbwan al-Safa represent the second course while Ibn Khaldun represent the third course. The effect of the course of philosophical education on management education is implementing educational philosophy in many management functions, namely the planning, implementation (classroom management) and evaluation.
\end{abstract}

Keyword; philosophy of Islamic education, education management

\section{A. Pendahuan}

Perjalanan panjang pendidikan islam yang telah tumbuh berkembang hingga saat ini sangat dipengaruhi oleh pemikiran tokohtokoh penggeraknya dalam melaksanakan sistem pembelajaran yang ada pada lembaga pendidikannya. Pemikiran tokoh penggerak pendidikan didorong oleh persinggungan antara realitas social cultural yang dihadapi tokoh tersebut dengan pemikiran agama yang mereka anut.

Peradapan Islam tidak lain adalah suatu hasil dari akumulasi perjalanan pergumulan penganut agama Islam ketika berhadapan dengan proses dialektis antara "normativis" ajaran wahyu yang permanen dan "historitas" pengalaman kekhalifahan manusia di muka bumi yang selalu berubah-rubah. ${ }^{1}$

Pendidikan Islam merupakan suatu bidang keilmuan yang sangat memerlukan upaya penelitian secara continue atau terus-menerus. Penelitian tersebut mencakup banyak hal, seperti administrasi, kurikulum, kelembagaan, organisasi, kebijakan, proses belajar mengajar, sampai

${ }^{1}$ M. Amin Abdullah, Falsafah Kalam, (Yogyakarta: Pustaka Pelajar, 2009), hlm. 3.

LITERASI, Volume. VI, No. 1 Juni 2014 
kepada pelaku pendidikan itu sendiri, yakni guru, bahkan penelitian terhadap keilmuan yang diajarkan. Pendidikan yang dilaksanakan berdasarkan penelitian ini dapat dipastikan akan mampu mengidentifikasi potensi yang dimilikinya serta keluar dari kemelut yang dihadapi dengan sejumlah alternatif solusi yang diperoleh melalui hasil penelitian (research based knowledge). ${ }^{2}$

Pendidikan Islam dalam teori dan praktek selalu mengalami perkembangan, hal ini disebabkan karena pendidikan Islam secara teoritik memiliki dasar dan sumber rujukan yang tidak hanya berasal dari nalar, melainkan juga wahyu. Kombinasi nalar dengan wahyu ini adalah ideal, karena memadukan antara potensi akal manusia dan tuntunan firman Allah SWT, terkait dengan masalah pendidikan. Kombinasi ini menjadi ciri khas pendidikan Islam yang tidak dimiliki oleh konsep pendidikan pada umumnya yang hanya mengandalkan kekuatan akal dan budaya manusia. ${ }^{3}$

Kemunculan Islam dalam pentas sejarah telah membebaskan nalar-pikir para pendidik dan ahli pendidikan dari ragam sekat yang memasung untuk kemudian kembali pada paradigma Islam. Dengan begitu, euforia pemikiran yang berkembang menjadi penuh dan saling melengkapi sejak dari wilayah Thus, Nishapur, Qabis, Qaeruwan, Baghdad, Damaskus hingga Kairo dan wilayah-wilayah lainnya. Sungguh, orientasi "keislaman" pada saat itu berimplikasi kuat terhadap pendidikan Islam di kalangan umat Islam. Pemikiran pendidikan kental dengan trend nuansa agamisnya, sehingga trend lain menjadi tidak dominan. Di saat seseorang dalam menafsirkan realitas dunia berpangkal pada agama, maka wajar dan logis bila agama sangat menjiwai pola pikir dan cara pandangnya hingga pendidikan pun dijadikannya sebagai instrumen terencana untuk mencapai tujuan. Jadi, para pendidik dan ahli pendidikan Muslim, setelah menjadikan tujuan keagamaan sebagai tujuan pendidikan, menyingsingkan lengan baju untuk mengarahkan segenap potensi diri menuju ke arah tujuan tersebut. ${ }^{4}$

Kentalnya perspektif keagamaan terhadap pendidikan di kalangan para ahli pendidikan Muslim menjadi bingkai perekat pemikiran mereka secara umum. Hanya saja, bingkai etik ini memang belum

${ }^{2}$ Abd. Rachman Assegaf, "Reorientasi Tradisi Keilmuan Pendidikan Islam dalam Perspektif Hadharah Al-'Ilm" dalam Ontologi Pendidikan Islam, Nizar Ali (ed.)(Yogyakarta: Penerbit Idea Press Yogyakarta, 2010), hlm. 20.

${ }^{3}$ Abd. Rachman Assegaf, Filsafat Pendidikan Islam: Paradikma Baru Pendidikan Haidhari Berbasis Integratif-Interkonektif, (Jakarta: PT RajaGrafindo Persada, 2011), hlm. 2

${ }^{4}$ Muhammad Jawwad Rido, Tiga Aliran Utama Teori Pendidikan Islam, terjemah Mahmut Arif, (Yogyakarta: Tiara Wacana Yogya, 2002), hlm. 59, 60 
mampu memunculkan cara pandang yang sama dalam pola operasionalisasi pendidikan dan dalam fungsi sosialnya, sebagaimana juga belum mampu menghasilkan kesepakatan dalam penyusunan kurikulum pendidikan dan kesatuan persepsi tentang sifat dasar dan kebutuhankebutuhan. Kenyataan demikian, kiranya tidak menyimpang dari "logika" arus dinamika peradaban Islam dan keragaman sentral-sentral pemikiran yang diback up oleh kelompok-kelompok sosial yang majemuk. Sangatlah mustahil bila para ahli pendidikan Muslim itu tidak berbeda dan beragam dalam pemahaman mereka tentang operasionalisasi pendidikan, mengingat mereka berada dalam kisaran arus deras pemikiran yang lahir dari asimilasi antara pemikiran murni keberagamaan dengan warisan budaya Helenistik, budaya India dan budaya Persia yang membahana di masa al-Makmun. ${ }^{5}$

Representasi ketokohan dalam pemikiran pendidikan Islam terdapat pada tujuh pemikir dan kelompok pemikir sistematis yaitu: Ibnu Sahnun (202 H-254 H), Al-Qabisi (342 H-256 H), Ikhwan al-Shafa (tim pengarang Rasa'il Ikhwan al-Shafa, abad IV Hijriyah), Al-Ghazali (450 H-505 H), Al-Thusi (597-672 H), Ibnu Jama'ah (639-733 H), Ibnu Khaldun (732-808 H), Ibnu Hajar al-Haitami (909-974 H). ${ }^{6}$ Tokoh-tokoh tersebut secara sistematik memberikan sumbangan nyata terhadap pemikiran pendidikan Islam: esensi, psikologi dan moralnya.

Artikel ini hanya akan mengkaji tiga tokoh, yaitu: al-Ghazali, Ikhwan al-Shafa dan Ibnu Khaldun. Sebab, mereka inilah yang paling merepresentasikan secara baik tiga aliran utama pendidikan Islam, yaitu aliran: konservatif, religious-rasional dan pragmatis instrumental. AlGhazali mewakili aliran pertama, Ikhwan al-Shafa mewakili aliran kedua, sedangkan Ibnu Khaldun mewakili aliran ketiga.

Implikasi beberapa aliran filsafat pendidikan Islam pada kontek manajemen pendidikan ternyata menimbulkan dampak yang luar biasa. Konsepsi pendidikan banyak berpengaruh pada pemantapan terhadap fungsi-fungsi manajemen untuk diterapkan pada komponen pendidikan utamanya pada fungsi perencanaan dan evaluasi pembelajaran.

\section{B. Aliran Konservatif (Al-Muhafidz)}

Aliran ini dalam bergumul dengan persoalan pendidikan cenderung bersikap murni keagamaan. Mereka memaknai ilmu dengan pengertian sempit, yakni hanya mencakup ilmu-ilmu yang dibutuhkan

${ }^{5} \mathrm{Ibid}, \mathrm{hlm} .70$.

${ }^{6}$ Ibid, hlm. 113-114

LITERASI, Volume. VI, No. 1 Juni 2014 
saat sekarang (hidup di dunia) yang jelas-jelas akan membawa manfaat kelak di akherat (al-Thusi dalam Adab al Muta'allim).

Penuntut ilmu berkeharusan mengawali belajarnya dengan Kitabullah Al-Quran. Ia berusaha menghafalkan dan mampu menafsirkannya. Ulumul Quran, karena itu merupakan induk semua ilmu, lalu dilanjutkan belajar al-Hadis dan Ulumul Hadis, Ushul, Nahwu dan Sharaf (lbnu ]ama'ah dalam Tadzkirat.).

Tokoh-tokoh aliran pemikiran pendidikan ini adalah al-Ghazali, Nasiruddin al-Thusi, Ibnu Jama'ah, Sahnun, lbnu Hajar al-Haitami dan al-Qabisi. Ragam ilmu, menurut aliran ini, diklasifikasikan menjadi:

Pertama, ilmu yang wajib dipelajari oleh setiap individu, yaitu ilmu tentang tatacara melakukan kewajiban yang sudah tiba saatnya dan ilmu-ilmu tentang kewajiban-kewajiban agama (Ulum al-Fara'idl alDiniyyah). Kedua, ilmu yang wajib kifayah untuk dipelajari, yaitu ilmu yang dibutuhkan demi tegaknya urusan kehidupan dunia, semisal: ilmu Kedokteran yang sangat krusial bagi pemeliharaan kesehatan badan, ilmu tentang pembekaman (bujamah) dan ilmu Hitung. Adapun ilmu-ilmu yang sekiranya terabaikan oleh warga suatu daerah, maka akan terjadi disharmoni kehidupan di daerah tersebut. Maksud wajib kifayah adalah apabila sebagian warga suatu masyarakat telah mempelajari ilmu tersebut, maka gugur kewajiban mempelajarinya bagi warga yang lain.

Al-Thusi menganalogikan jenis ilmu yang pertama dengan makanan pokok, sedangkan jenis ilmu yang kedua dianalogikan dengan obat yang hanya dimakan sewaktu terpaksa. Selain dua jenis ilmu itu, ada pula ilmu yang hukum mempelajarinya termasuk fadlilah (keutamaan, anjuran), seperti pendalaman lebih lanjut tentang detailnya ilmu Hitung dan ilmu Kedokteran. Dalam pada itu, ragam ilmu yang ada dapat pula dipilah menjadi ilmu terpuji dan ilmu yang tercela. Menurut al-Gazali ilmu-ilmu cabang, ilmu-ilmu alat dan ilmu-ilmu pelengkap termasuk di dalamnya Filsafat dibagi menjadi empat bidang:

1. Ilmu Ukur dan ilmu Hitung. Disiplin ilmu ini diperbolehkan untuk dipelajari dan dilarang hanya bila jeias-jelas membahayakan bagi yang bersangkutan karena dapat mengantarkannya ke ilmu yang tercela.

${ }^{7}$ Nashiruddin al-Thusi, Shahib al-llm al-Riyadl dan Jami' al-Ulum aI-Mutaqaddimin wa al-Muta'akhkhin. AI-Thusi lahir pada tahun $597 \mathrm{H}$ dan meninggal pada tahun pada tahun $672 \mathrm{H}$, Para sejarawan sepakat bahwa ia adalah penulis produktif dalam berbagai disiplin ilmu dan teknologi. Diantara karya tulisnya yang populer adalah adalah: al-Syakl wa al-Qutha', al-Risalah al-Syafiah an al-Syak fi al-Khutut al Mutawaziah, Tahrir Uslul Eqledis, Dhahiratu al-Falak, Zaij al-Syahi wa al-Tadzkirat fi llmi al-Hai'at (ilmu Astronomi) dan alTashil fi ilmi al-Nujum. Karya tulisnya tentang pendidikan adalah Kitab Adab al-Muta'allim. 
2. Ilmu Mantik (Logika), yaitu ilmu yang berkenaan dengan bentuk dalil (argumentasi), syarat-syaratnya, bentuk berargumentasi dan syaratsyaratnya. Unsur dasar ilmu ini masuk ke dalam ilmu Kalam.

3. Ilmu ketuhanan (Teologi), yaitu ilmu yang berisi kajian tentang dzat Tuhan.

4. Ilmu kealaman. Sebagian ilmu ini bertentangan dengan syara', agama dan kebenaran. Inilah bentuk kebodohan dan bukan ilmu pengetahuan; sebagian lainnya mengkaji tentang anatomi tubuh, rincian organ-organ dan perubahan-perubahannya. Hal ini mirip dengan pandangan para dokter. Hanya saja dokter lebih unggul dan lebih dibutuhkan.

Pandangan "konservatif" tersebut mengarah pada konsep hirarkhi nilai yang menstrukturkan ragam ilmu secara vertikal sesuai dengan penilaian mereka tentang keutamaan masing-masing ilmu. Hirarkhi nilai tersebut menyingkap "arti penting" yang mereka sandarkan pada masing-masing ilmu. Setelah membagi potensi manusia yang mengejawantah ke dalam ragam pengetahuan berdasar prinsip tujuan keagamaan, menjadikan fungsinya sebagai parameter keutamaan di antara berbagai ilmu, al-Ghazali menegaskan bahwa ilmu-ilmu keagamaan yakni pengetahuan tentang jalan menuju akhirat hanya dapat diperoleh dengan kesempurnaan rasio dan kejernihan akal budi. Rasio adalah sifat manusia yang paling utama, karena hanya dengan rasiolah manusia mampu menerima amanat dari Allah dan dengannya pula mampu "mendekat" di sisi-Nya.

Lebih jauh Ibnu Jama'ah mengulas hal ini. Menurutnya, apabila program studi sangat banyak dan beragam, maka yang diprioritaskan adalah program studi yang lebih utama dan lebih penting. Karena itu, perlu diprioritaskan studi tafsir Al-Quran, Hadis, Ushul Fiqh, pemikiran Madzhab (baca: Syafi'iyyah), lalu perbedaan-perbedaan yang ada, ilmu Nahwu atau ilmu debat (jadal).

\section{Aliran Religius-Rasional (Al-Diniy-Al-`Aqlaniy)}

Aliran ini tidak jauh berbeda dengan pemikiran kalangan "tradisionalis-tekstualis" atau konservatif, dalam hal relasi pendidikan dengan tujuan agamawi. Ikhwan al-Shafa mengakui bahwa semua ilmu dan sastra yang tidak mengantarkan pemiliknya menuju concern terhadap akherat dan tidak memberikan makna sebagai bekal di sana, maka ilmu demikian hanya akan menjadi bumerang bagi si pemilik tadi kelak di akhirat. Namun, kalangan Religius-Rasional tampak punya perbedaan sewaktu, 
"menggumuli" persoalan pendidikan karena cenderung bersikap rasionalfilosofis. Kecendurangan rasional-filosofis itu secara eksplisit terungkap dalam rumusan mereka tentang ilmu dan belajar yang jauh berbeda dengan rumusan kalangan tradisionalis-tekstualis.

Ikhwan al-Shafa, salah satu representasi dari aliran ReligiusRasional, merumuskan ilmu sebagai berikut: "Ketahuilah bahwa ilmu adalah gambaran tentang sesuatu yang diketahui pada benak (jiwa) orang yang mengetahui. Lawan dari ilmu adalah kebodohan, yaitu tiadanya gambaran yang diketahui pada jiwanya. Ketahuilah bahwa jiwa para ilmuwan, secara riil-aktual berilmu, sedangkan jiwa para pelajar itu, berilmu secara potensial. Belajar dan mengajar tiada lain adalah mengaktualisasikan hal-hal potensial, melahirkan hal-hal yang "terpendam" dalam jiwa. Aktivitas seperti itu bagi guru (orang yang berilmu) dinamakan dengan mengajar, dan bagi pelajar dinamakan dengan belajar. Dalam rumusan formulatifnya, terungkap dasar-dasar teori pengajaran.

Ikhwan al-Shafa menempatkan filsafat di atas agama. Mereka mengharuskan filsafat menjadi landasan agama yang dipadukan dengan ilmu. Kesimpulan ini didukung dengan pendapat mereka dalam bidang agama agar cocok dengan tingkatan nalar orang Arab Badui yang berkebudayaan bersahaja. Sedangkan bagi yang memiliki pengetahuan yang lebih tinggi mereka haruskan memakai ta'wil untuk melepaskan diri dari pengertian lafzi dan inderawi. Untuk itulah Ikhwan berusaha dengan gigih memadukan filsafat dengan agama dengan menurunkan metafisika dan ilmu pengetahuan dari puncak spekulatif murni yang tidak dapat dijangkau secara aktif praktis. ${ }^{9}$

Jiwa pelajar adalah berilmu (mengetahui) secara potensial. Artinya, berkesiapan untuk belajar, atau menurut istilah pendidikan sekarang, educable (kesiapan ajar). Proses pengajaran tiada lain adalah usaha transformatif terhadap kesiapan-ajar agar benar-benar menjadi riil, atau dengan kata lain, upaya transformafif terhadap jiwa pelajar yang semula berilmu (mengetahui) secara potensial agar menjadi berilmu (mengetahui) secara riil-aktual. Dengan demikian, inti proses pendidikan adalah pada kiat transformasi potensi-potensi manusia agar menjadi kemampuan "psiko-motorik". Konsepsi seperti ini jelas jauh dari konsep pengetahuan intuitif yang cenderung diapresiasi oleh kalangan aliran Konservatif dalam pemikiran pendidikannya. Akan dapat dilihat nanti,

\footnotetext{
${ }^{8}$ Muhammad Jawwad Rido, Tiga Aliran Utama Teori Pendidikan Islam, terjemah Mahmut Arif, (Yogyakarta: Tiara Wacana Yogya, 2002), hlm. 77, 78.

${ }^{9}$ Hasyimsyah Nasution, Filsafat Islam (Jakarta: Gaya Media Pratama, 2005), hlm.47. 
bagaimana aliran Religius-Rasional banyak membangun konsepkonsepnya dari pemikiran filsafat Yunani dan berusaha menyelaraskan pemikiran filsafat Yunani dengan pandangan-pandangan dasar dari orientasi keagamaan mereka.

Diantara tokoh aliran Religius-Rasional yang dapat disebutkan adalah: kelompok lkhwan al-Shafa, al-Farabi, Ibnu Sina dan Ibnu Maskawaih. Diakui bahwa, kelompok Ikhwan al-Shafa, banyak bicara atas-nama aliran ini. Mereka secara "ensiklopedis" telah mengelaborasi gagasan-gagasan penting aliran Religius-Rasional. Karena itu, sudah sepantasnya jika kelompok Ikhwan mendapat porsi ulasan yang lebih banyak.

Hal pertama yang menjadi sasaran bidik pemerhati atau pengkaji pemikiran kelompok Ikhwan al-Shafa dan tokoh-tokoh lain yang sealiran adalah pergumulan intensifnya dengan rasionalitas Yunani dalam berbagai segi, sampai-sampai mereka dijuluki "pemburu" hikmah (filsafat) Yunani di belahan dunia Timur. Selain itu, pergumulan intensif mereka telah memberikan landasan bagi aliran pendidikannya, yakni bahwa pangkal segala sesuatu yang terkait dengan jiwa (diri) beserta semua potensinya, serupa dengan apa yang diutarakan oleh kecenderungan Gnostik. ${ }^{10}$

Al-Farabi telah menganalisis manusia secara "fungsionalorganik". Ia memilah-milah potensi (sumber-daya insani) yang dimiliki manusia menjadi enam tingkatan yang merupakan totalitas eksistensi perkembangannya. Menurut al-Farabfi, jika anak manusia lahir, maka potensi organik pertama yang berfungsi adalah potensi al-ghadziyyah (organ-organ tubuh yang berguna untuk mencerna makanan). Setelah ini, diikuti potensi "perasa", sehingga dia bisa merasakan semisal hawa dingin atau panas, juga dapat merasakan stimuli warna dan kilasan cahaya. Bersamaan dengan berfungsinya potensi inderawiah itu, timbul kecenderungan-kecenderung pada diri si anak untuk merespons dan

10 Prof. Philip mendefinisikan Gnostik sebagai "kepercayaan" aliran pengetahuan di Yunani di mana seseorang (penuntut ilmu) bisa mencapai pengetahuuan/kepercayaan tadi dengan adanya "kilasan" cahaya batin. Kepercayaan itu bukanlah pengetahuan tentang Tuhan yang bisa diperoleh melalui premis-penalaran rasio. Menurut Philip, kalangan Sufisme juga terpengaruh aliran tersebut semenjak abad II H, dan jadilah metode sufistik, bagi para penganutnya, scbagai jalan "emotif" untuk mcmbcrsihkan jika manusia agar bisa meengenal (makrifat) Allah dan sampai pada mahabah (cinta) kepadaNya semata "bersatu" denganNya semata-mata karena landasan cinta dan keinginan bersatu, bukan karena ingin memperoleh ridla dan pahala kelak di akhirat.

LITERASI, Volume. VI, No. 1 Juni 2014 
bereaksi. Lalu, potensi-potensi itu mempersepsi dan menghafal stimulistimuli inderawiah yang telah diterimanya. Inilah potensi mutakhayyilah (imajinasi). Potensi ini mengasosiasikan dan memilah-milahkan unsurunsur stimuli dengan aneka model, sebagian ada yang realistik, sebagian yang lain ilusif. Dalam perkembangan selanjutnya, tumbuh potensi "mengabstraksi" (al-muthlaqab), yakni potensi yang memungkinkan menalar, mengidentifikasi antara yang indah dan yang jelek, potensi yang memungkinkan berkreasi dan berinovasi.

Jelaslah, dalam analisa konseptualnya tentang tahap-tahap perkembangan manusia itu, secara tersirat al-Farabi menghendaki agar operasionalisasi pendidikan seiring dengan tahap-tahap perkembangan fungsi organ tubuh dan kecerdasan manusia, sehingga tidak terjadi "pemaksaan" sebelum masa tahap perkembangannya tiba. Sebab, jika sampai terjadi demikian akan berimplikasi pada kacaunya tatanan perkembangan alamiahnya.

Teori pengetahuan Ikhwan al-Shafa didasarkan pada asumsi bahwa pengetahuan merupakan gambaran sesuatu yang diketahui dalam jiwa orang yang mengetahui. Hal ini mirip dengan pendapat Plato dalam bukunya Republic, di mana ia mengaitkan pengetahuan dengan kebajikan utama (keadilan) dan menganggap pengetahuan itu beremanasi darinya. Adapun faktor penyebab eternalitas akal adalah "dukungan" Tuhan terhadap ekstensi akal dan emanasinya yang telah terjadi sejak awal-kali, sedangkan faktor penyebab kesempurnaan akal adalah akseptabilitas (daya-terima) terhadap emanasi, keutamaan-keutamaan dan " supporting " dari Tuhan.

Kalangan Ikhwan al-Shafa mengakui prinsip dasar material bagi pengetahuan manusia. Hal ini ditunjukkan oleh penegasannya terhadap arti penting indera bagi penataan relasi makhluk hidup (baca: manusia) dengan lingkungan eksternalnya. Mereka membedakan indera (al-hawas) dengan daya inderawi/ empirik (al- quwwa al-hassah). Yang pertama adalah "tempat" bagi yang kedua. Menurut mereka, indera adalah sarana jasadiah yang jumlahnya ada lima, yaitu; mata, telinga, lidah, hidung dan tangan, sedangkan daya inderawi adalah daya jiwa yang secara spesifik dimiliki oleh masing-masing organ tubuh. Hal-hal inderawi adalah sesuatu yang dicerap oleh indera. Dan hal yang telah dicerap oleh indera adalah aksiden-aksiden dari benda-benda fisik yang rnempengaruhi indera dan mengubah "mekanisme" di dalamnya. Dengan demikian apakah pennyerapan inderawi (al-hiss) itu? Ia adalah perubahan mekanisme dalam indera, karena adanya rangsangan dari hal-hal yang tercerap oleh indera. Pengamatan (al-ihsas) adalah terangsangnya daya 
inderawi (modalitas pengamatan) untuk mengubah mekanisme dalam indera. Meskipun indera adalah organ material (fisik) dari tubuh manusia, namun masing-masing fungsinya terkait dengan daya psikis, seperti: daya imajinasi, daya mengabstraksi, memori, berpikir dan psikomotorik, yang diistilahkan ikhwan dengan daya-daya kejiwaan (qumwa rubaniyyah).

Di kala al-Ghazali menyerang habis-habisan ilmu kealaman dan menganggapnya sebagai hal yang bertentangan dengan syariat dan kebenaran, serta tidak mengakuinya sebagai hal yang dibutuhkan oleh manusia, kalangan Ikhwan al-Shafa dan Rasionalis lainnya justru menempatkan ilmu kealaman dalam daftar klasifikasi ilmu mereka pada posisi "terhormat" setingkat dengan kedudukan ilmu riyadliyyat (matematik) atau ilmu syar'iy (ilmu agama), lalu mereka memperluas cakupan ilmu kealaman itu hingga meliputi:

1. Prinsip-prinsip dasar kejasmanian (terdiri lima cabang, yaitu hule (isi), morfe (bentuk), ruang, waktu dan gerak) dan hal-hal yang mungkin terjadi bila dilakukan kombinasi.

2. Astronomi dan Astrologi.

3. Ilmu penciptaan dan kerusakan alam (Ekologi).

4. Metreologi: pengetahuan tentang perubahan cuaca akibat dari pengaruh edar planet planet.

5. Ilmu pertambangan (Geologi): pengetahuan tentang bahan-bahan tambang yang berasal dari endapan pada perut bumi, "ampas-ampas" yang furun dari udara/ rongga-rongga gunung dan lapisan dasar laut.

6. Ilmu Botani.

7. Ilmu hewan: pengetahuan tentang jenis-jenis binatang hidup, karakteristik-nya, pembudidayaan dan pemeliharaan binatang ternak, binatang buas, burung dan sebagainya.

Sikap kalangan Ikhwan al-Shafa demikian, yang diikuti juga oleh Ibnu Miskawaih, al-Farabi dan Ibnu Sina, merupakan pengejawantahan dari kesadaran baru tentang nilai (guna) ilmu bagi kehidupan manusia dan kesetaraan nilai dari ragam ilmu yang ada. Implikasinya, konsep ilmu menurut mereka berpangkal pada "kesedia-kalaan" ilmu tanpa pembatasan. Hal ini memiliki arti penting dalam rangka pemancangan arah peradaban masyarakat Arab Islam.

\section{Aliran Pragmatis (Al-Dzarai'iy)}

Ibnu Khaldun adalah tokoh satu-satunya dari aliran ini. Pemikirannya, meskipun tidak kurang komprehensifnya dibanding kalangan Rasionalis, dilihat dari sudut pandang tujuan pendidikan, lebih 
banyak bersifat pragmatis dan lebih berorientasi pada aplikatif-praktis. Dia mengklasifikasikan ilmu pengetatahuan berdasar tujuan fungsionalnya, bukan berdasar nilai substansialnya semata. Dengan hal itu, ia membagi ragam ilmu yang perlu dimasukkan ke dalam kurikulum pendidikan menjadi dua bagian:

1. Ilmu-ilmu yang bernilai instrinsik, semisal ilmu-ilmu, syar'iyyat (keagamaan): Tafsir, Hadis, Fikih, Kalam; Ontologi danTeologi dari cabang Filsafat.

2. Ilmu-ilmu yang bernilai ekstrinsik-instrumental bagi ilmu-ilmu jenis pertama, semisal kebahasa-Araban, ilmu Hitung dan sejenisnya bagi ilmu syar'iy, Logika bagi Filfasat dan bahkan menurut ulama' Muta'akhirin, dimasukkan pula ilmu Kalam dan Usul Fikih. ${ }^{11}$

Aliran Pragmatis yang digulirkan Ibnu Khaldun merupakan wacana baru dalam pemikiran pendidikan Islam. Bila kalangan Konservatif mempersempit ruang lingkup "sekuler" di hadapan rasionalitas Islam dan mengaitkannya secara kaku dengan pemikiran atau warisan Salaf, sedangkan kalangan Rasionalis dalam sistem pendidikan (program kurikuler) berpikiran idealistik sehingga memasukkan semua disiplin keilmuan yang dianggap substantif bernilai, maka Ibnu Khaldun mengakomodir ragam keilmuan yang nyata terkait dengan kebutuhan langsung manusia, baik berupa kebutuhan spiritual-rohaniah maupun kebutuhan material.

Ibnu Khaldun sejalan dengan kalangan Rasionalis dalam hal pengakuan rasio (al-'aql) atau daya pikir (al-fiker) sebagai sumber otonom dari sumber-sumber pengetahuan lainnya dan menjadikan kajian tentang realitas kebenaran sebagai penentu utama eksistensi manusia. Bahwa manusia mempunyai kesamaan dengan hewan dalam banyak hal: kepekaan terhadap rangsangan, gerak, makan-minum dan sebagainya, namun berbeda dengan hewan pada daya pikinnya yang menjadi instrumen pemerolehan penghidupan dan kooperasi dengan sesama. Dari daya pikir itu, muncul ragam ilmu dan ketrampilan manufaktur. Dalam kerangka daya pikir dan watak dasar manusia, bahkan juga hewan, yang cenderung ingin mendapatkan basic need (kebutuhan kodrati), wajar bila daya pikir lebih cenderung memperoleh pengetahuan-pengetahuan baru yang belum dimiliki, dengan merujuk pada orang yang lebih dulu tahu atau merujuk pada generasi terdahulu dari kalangan para nabi yang telah menyampaikan warta kebenaran. Selanjutnya, eksplorasi intelektual daya pikir (rasio) mengarah pada satu persatu realitas kebenaran dan mencermati hal-hal yang didapatinya secara berulang, sehingga tumbuh

${ }^{11}$ Ibnu Khaldun, al-Muqaddimah, (Kairo: al-Maktabah al-Tijariyah, tt), hlm. 536. 
capability intelektual dan menghasilkan pengetahuan istimewa. Lalu, generasi yang datang belakangan berhasrat untuk memperoleh pengetahuan itu. Mereka berbondong-bondong pergi belajar pada orang yang sudah mengetahuinya, sehingga terselenggaralah pengajaran. Dengan demikian ilmu pengetahuan dan pengajaran merupakan hal alami dalam kehidupan manusia. ${ }^{12}$

Walaupun Ibnu Khaldun telah berusaha memadukan antara peran rasio dengan peran naql dalam perkembangan pengetahuan manusia, namun terkesan adanya kecenderungan rasionalisnya sewaktu mengungkapkan, entah disadari atau tidak, peran rasio yang sangat menentukan dalam perkembangan pengetahuan manusia, yaitu pertama, ketika ia menegaskan bahwa al-fiker (daya pikir, rasio) itbu berkecenderungan memperoleh sesuatu yang tidak diketahuinya. Kedua, ketika ia menjadikan eksplorasi intelektual terhadap satu persatu realitas dan berbagai gejala yang timbul sebagai "pangkal" pencapaian pengetahuan istimewa dan mendalam. Ia memahami hal ini sebagai metode objektif dalam penyingkapan hukum-hukum alam. Dan ketiga, ketika ia menyimpulkan bahwa ilmu pengetahuan dan pengajaran merupakan hal alami dalam kehidupan manusia, sehingga rasio manusia (al-fkr) berkompeten untuk melakukan pengkajian realitas kebenaran secara otonom tanpa ada ijazah atau izin dari penguasa tertentu.

\section{E. Implikasinya Terhadap Manajemen Pendidikan Islam}

Pembahasan mengenai manajemen pendidikan tidak bisa dipisahkan dari bahasan yang terkait dengan pengertian manajemen dan pendidikan di satu sisi dan pembahasan administrasi dan pendidikan pada sisi yang lain. Sedangkan Para pakar yang mendefinisikan manajemen yang berakar dari manajemen bisnis menyatakan bahwa manajemen pendidikan pada dasarnya adalah pengelolaan fungsi-fungsi atau langkah-langkah manajemen yang diaplikasikan pada lembaga pendidikan. Dalam pengertian, manajemen merupakan sebuah seni dan ilmu mengelola sumber daya pendidikan guna mencapai tujuan yang telah ditentukan secara efektif dan efesien.

Para ahli pendidikan Muslim menyadari sepenuhnya bahwa pembelajaran merupakan hal yang sangat unik dan kompleks, sebagaimana profesi-profesi lain, yang menuntut dimilikinya persyaratan tertentu oleh orang yang menekuninya. Ibnu Abdun berkata, "Sesungguhnya pengajaran itu merupakan profesi yang membutuhkan

${ }^{12}$ Ibid, hal. 430.

LITERASI, Volume. VI, No. 1 Juni 2014 
pengetahuan, ketrampilan dan kecermatan, karena ia sama halnya dengan pelatihan kecakapan yang memerlukan kiat, strategi dan ketelatenan, sehingga menjadi cakap dan profesional ${ }^{13}$. Pada kontek manajemen pendidikan maka hal sebagaimana disebutkan di atas sangat terkait dengan perencanaan. Pembelajaran membutuhkan perencanaan yang matang mualai dari menganalis tujuan pembelajaran, penyiapan strategi, metode, media, materi dan cara evaluasi pembelajaran. Segenap langkah tersebut akan dapat dilakukan secara optimal apabila didukung dengan kompetensi dan kualifikasi guru yang memadahi.

Bermula dari perspektif profesionalitas-teknikalis, para ahli pendidikan Muslim membedakan 'secara tegas antara pendidikan (altarbiyah) dan pengajaran (al-ta'lim). Menurut mereka yang pertama ruang lingkupnya lebih luas dibanding yang kedua. Maka dari itu, al-Ghazali menasihati orang-orang yang bertanggung jawab atas anak-anak agar menyadari sepenuhnya;

"Pendidikan anak tidak hanya terbatas pada pengajaran semata. Si penanggung jan'ab berkewajiban mengawasi anak dari hal sekecil dan sedini mungkin. Ia jangan sampai menyerahkan anak yang berada di bawah tanggung jawabnya untuk diasuh dan disusui kecuali oleh perempuan yang baik, agamis dan hanya memakan sesuatu yang halal. Seyogya ya, secara cermat mengawasi anak semenjak dini, menumbuhkembangkan rasa malu pada diri anak, dan mengarahkannya agar tidak berlebihlebihan dalam makan dan minum". Al-Ghazali lebih jelas menambahkan, "pendidikan itu mirip seperti pekerjaan seorang petani yang menyiangi duri dan rerumputan agar tanamannya bisa tumbuh dan berkembang dengan baik"

Keseriusan menangani urusan anak membawa para ahli pendidikan pada kesadaran bahwa aktivitas pendidikan dimulai dari semenjak awal kehidupan. Dalam risalah politiknya, Ibnu Sina mengatakan, "Sudah menjadi kewajiban orang tua memberi nama yang baik untuk anaknya dan memilih sang perempuan yang akan menyusui dan mengasuhnya. Jangan sampai berupa perempuan yang lemah akal dan liar atau perempuan yang mengidap jenis penyakit menular. Bila anak telah disapih, mulailah dengan pendidikan moral dan pembentukan akhlak, sebelum ia terlanjur menyerap moral tercela dan perangai hina. Sebab, anak akan gampang dengan segera menerima moral jelek dan

13 Ahmad al-Syalabi, Tarikh al-Tarbiyah al-Islamiyah, cet. II, (Kairo: tnp., 19610, hlm. 174. 
rangsangan-rangsangan buruk dari luar. Bila ia terus-menerus menerima rangsangan buruk, maka akan sulit baginya lepas dari perangai jelek. Oleh karena itu, seharusnya pendidik menjauhkan anak dari moral buruk.

Berangkat dari kajian konsep pengajaran, terdapat beberapa dasar psikologis pendidikan yang sangat penting yang bisa diambil dari pemikiran para ahli pendidikan Muslim. Hal pertama kali yang mereka sadari, bahwa al-idra (kognisi) adalah dasar utama pembelajaran. Al-Thusi berkata; "Seorang subjek didik tidak bisa memperoleh sesuatu yang tidak ia pahami. Karena itu mengharuskan si subjek didik agar mengawali aktivitas belajar dari hal yang paling dekat dengan pemahamannya. Dan hendaknya juga guru membatasi diri mengajarkan materi yang sesuai dengan kadar pemaharnan subjek didiknya. la tidak boleh mengajarkan materi di luar kemampuan nalar subjek didik sehingga bisa menjadikannya putus asa atau semakin bebal".

Al-ghazali dalam Ihya' mengatakan "Sekiranya subjek didik bersusah-payah untuk memperoleh ilmu dengan usaha yang melebihi kemampuan dirinya dan (bahkan) sang guru sendiri pun merasa khawatir untuk melarangnya, hendaklah ia berpesan agar subjek didik peduli terhadap dirinya sendiri", kata Ibnu Jama'ah dalam Tadzkirat al-Sani'. Para ahli pendidikan muslim mengharuskan guru untuk memberi perlakuan yang berbeda terhadap subjek didik yang cerdas dan subjek didik yang berkemampuan terbatas. Guru mengajarkan materi yang jelas dan sederhana, agar dapat dipahami oleh subjek didik yang berkemampuan terbatas ini; jangan sampai guru menyampaikan kepadanya materi yang rumit dan kompleks, sebab hal ini dapat menyurutkan minat dan animonya untuk belajar (al-Ghazali dalam Ibya).

Bukti kesadaran para ahli pendidikan Muslim akan adanya hubungan erat antara potensi-potensi intelektual subjek didik dengan materi keilmuan yang diajarkan padanya, Ibnu jama'ah mengingatkan para guru mengenai keharusan mereka membeberkan dan memerinci materi yang disampaikan, sehingga mudah dipahami oleh para subjek didik, dan ini merupakan keteladanan yang telah ditunjukkan Nabi; "Pembicaraannya begitu terperinci dan gamblang, sehingga yang mendengar mudah memahaminya. Sewaktu mengucapkan kata-kata penting, diulangnya tiga kali agar dipahami, dan di saat rampung membicarakan suatu persoalan, beliau berhenti sejenak memberi kesempatan orang lain bertanya atau berbicara", demikian kata Ibnu Jama'ah dalam 'Tadzkirat al-Sami'.

Pada kontek manajemen pendidikan, hal di atas sangat terkait dengan pengelolaan kelas, sebagai salah satu tugas utama guru pada sisi 
pelaksanaan pembelajaran setelah dilaksanakan perencanaan sebelumnya. Pengelolaan kelas harus didasarkan kepada situasi dan kondisi dari siswa sebagai subjek belajar. Guru harus peka terhadap kondisi siswa, mengetahui kebutuhan siswa, tantangan siswa, sehingga guru bisa mengarahkan dan mengintervensi siswa sesuai dengan tujuan pembelajaran yang diharapkan.

Berdasarkan hal itu, para ahli pendidikan muslim melarang pencampuran ragam ilmu untuk diajarkan kepada subjek didik pemula, karena dikhawatirkan bisa mengacaukan pikirannya. Ibnu Khaldun berkata, "Terrnasuk pola yang baik dan cara yang harus ditempuh dalam pengajaran adalah tidak dicampurkan dua (atau lebih) disiplin ilmu untuk diajarkan pada subjek didik. Ia menuntut agar pengajaran ragam ilmu pengetahuan dilaksanakan secara bertahap, dari yang sederhana menuju hal yang kompleks seiring dengan taraf kematangan dan kesanggupan subyek didik dalam menguasainya. "Apabila hal yang semestinya diajarkan pada tingkat lanjut, diajarkan pada tingkat awal, maka ia akan mengalami ketidak sanggupan dalam memahami dan jauh dari kesiapan diri untuk belajar, sehingga perolehan ilmu terasa amat sulit. Selanjutnya, ia rnenjadi malas dan berpaling dari konsentrasi belajar. Dan hal ini akan berakibat pada jeleknya pengajaran". ${ }^{14}$ Termasuk prinsip dasar pendidikan, adalah penegasan para ahli pendidikan Muslim bahwa usia yang pantas untuk pengajaran awal adalah enam tahun. Ibnu Sina dalam al-Qanun berkata, "Jika usia anak telah mencapai enam tahun, maka ia sudah seharusnya dibawa kepada guru untuk belajar serius dan intensif".

Aspek terakhir pada manajemen pendidikan yaitu evaluasi. Evaluasi pembelajaran akan sangat terkait dengan upaya mengetahui tingkat kemampuan peserta didik terhadap segala materi yang disampaikan oleh guru kepada peserta didik. Tingkat capaian peserta didik terhadap materi yang telah disampaikan harus selalu dikorelasikan dengan tujuan dalam perencanaan yang telah ditetapkan sebelumnya.

14 Ibnu Khaldun, al-Muqaddimah, hlm 533. 


\section{F. Penutup}

Munculnya pluralitas pemikiran dan kecenderungan (aliran) di kalangan ahli pendidikan Islam merupakan fenomena wajar dan sehat dalam bingkai peradapan yang mengenal pasang surut, dan mengalami kemajuan dan kemunduran, seiring dengan dinamika dan konstraksi masyarakat.

Secara umum filsafat pendidikan Islam adalah merupakan perpaduan antara nalar dan wahyu. Dengan mempelajari dan memahami pemikiran pendidikan Islam maka diharapkan kita mampu melakukan rekontektualisasi dan rekonseptualisasi pendidikan Islam yang relevan dengan kebutuhan masa sekarang. 


\section{DAFTAR PUSTAKA}

Abd. Rachman Assegaf, "Reorientasi Tradisi Keilmuan Pendidikan Islam dalam Perspektif Hadharah Al-'Ilm" dalam Ontologi Pendidikan Islam, Nizar Ali (ed.), Yogyakarta: Penerbit Idea Press Yogyakarta, 2010.

Abd. Rachman Assegaf, Filsafat Pendidikan Islam: Paradikma Baru Pendidikan Haidhari Berbasis Integratif-Interkonektif, Jakarta: PT RajaGrafindo Persada, 2011

Ahmad al-Syalabi, Tarikh al-Tarbiyah al-Islamiyah, cet. II, Kairo: tnp., 1961.

Al-Ghazali, lbya' Ulum al-Din, Kairo: al-Istiqamah, tt.

Al-Thusi, Kitab Adab al-Muta'allin.

Hasyimsyah Nasution, Filsafat Islam, Jakarta: Gaya Media Pratama, 2005.

Ibnu Khaldun, al-Muqaddimah, Kairo : al-Maktabah al-Tijariyah, $1327 \mathrm{H}$.

Ikhwan al-Shafa, Rasa'il lkhwan al-Shafa, Kairo: al-Mathba'ah al-Arabiyyah, 1928.

Muhammad Jawwad Rido, Tiga Aliran Utama Teori Pendidikan Islam, terjemah Mahmut Arif, Yogyakarta: Tiara Wacana Yogya, 2002.

M. Amin Abdullah, Falsafah Kalam, Yogyakarta: Pustaka Pelajar, 2009.

Philip Hittl, Tarikh al-Arab, Beirut: tnp., 1951. 